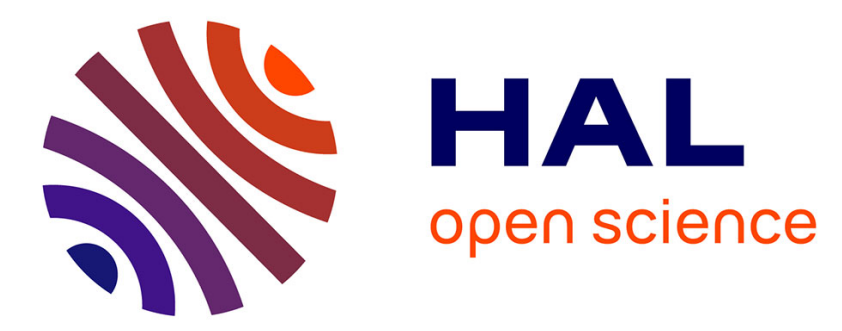

\title{
Self-provided microbial electricity enhanced wastewater treatment using carbon felt anode coated with amino-functionalized $\mathrm{Fe} 3 \mathrm{O} 4$
}

Hongbo Liu, Yi Zhang, Yanhong Zhou, Zhongbing Chen, Eric Lichtfouse

\section{- To cite this version:}

Hongbo Liu, Yi Zhang, Yanhong Zhou, Zhongbing Chen, Eric Lichtfouse. Self-provided microbial electricity enhanced wastewater treatment using carbon felt anode coated with amino-functionalized Fe3O4. Journal of Water Process Engineering, 2020, 38, 10.1016/j.jwpe.2020.101649 . hal-03038450

\author{
HAL Id: hal-03038450 \\ https://hal.science/hal-03038450
}

Submitted on 3 Dec 2020

HAL is a multi-disciplinary open access archive for the deposit and dissemination of scientific research documents, whether they are published or not. The documents may come from teaching and research institutions in France or abroad, or from public or private research centers.
L'archive ouverte pluridisciplinaire HAL, est destinée au dépôt et à la diffusion de documents scientifiques de niveau recherche, publiés ou non, émanant des établissements d'enseignement et de recherche français ou étrangers, des laboratoires publics ou privés. 


\title{
Self-provided microbial electricity enhanced wastewater treatment using carbon felt anode coated with amino-functionalized $\mathrm{Fe}_{3} \mathrm{O}_{4}$
}

\author{
Hongbo Liu $^{\mathrm{a}, *}$, Yi Zhang ${ }^{\mathrm{a}}$, Yanhong Zhou ${ }^{\mathrm{a}}$, Zhongbing Chen ${ }^{\mathrm{b}}$, Eric Lichtfouse ${ }^{\mathrm{c}}$ \\ ${ }^{a}$ School of Environment and Architecture, University of Shanghai for Science and Technology, 516 Jungong Road, 200093, Shanghai, China \\ ${ }^{\mathrm{b}}$ Faculty of Environmental Sciences, Czech University of Life Sciences Prague, Kamýcká 129, 16500 Prague, Czech Republic \\ ${ }^{\mathrm{c}}$ Aix-Marseille Univ, CNRS, IRD, INRA, Coll France, CEREGE, 13100 Aix en Provence, France
}

A R T I C L E I N F O

\section{Keywords:}

Self-provided microbial electricity

Microorganism attachment

Enhanced wastewater treatment

Amino-functionalization

Microbial power production

\begin{abstract}
A B S T R A C T
Bioelectricity can be produced from wastewater using microbial fuel cells (MFCs) that produce electricity during electrochemical and biochemical reactions, yet actual applications of wastewater MFCs are limited; a selfprovided microbial electricity enhanced wastewater treatment method is proposed producing microbial power and enhanced pollutants removal simultaneously. A carbon felt coated with amino-functionalized $\mathrm{Fe}_{3} \mathrm{O}_{4}$ particles was synthesized; power generation, removal of chemical oxygen demand (COD) and $\mathrm{NH}_{4}^{+}-\mathrm{N}$ were evaluated with cyclic voltammetry (CV), electrochemical impedance spectroscopy (EIS), cell voltage and treatment efficiency. Results showed that the amino- $\mathrm{Fe}_{3} \mathrm{O}_{4}$ coated anode led to higher $\mathrm{NH}_{4}^{+}-\mathrm{N}$ removal efficiency of $97.7 \%$ than the $\mathrm{Fe}_{3} \mathrm{O}_{4}$ coated anode of $48.9 \%$. Moreover, the maximum power density of the amino- $\mathrm{Fe}_{3} \mathrm{O}_{4}$ anode is $208.67 \mathrm{~mW} /$ $\mathrm{m}^{2}, 35.1 \%$ higher than that of the $\mathrm{Fe}_{3} \mathrm{O}_{4}$ anode. This finding was explained by the presence of protonated amino groups $\mathrm{NH}_{4}^{+}$that favored the attachment of negatively charged bacteria. Amino-functionalization of the anode promotes a promising, novel technology to treat wastewater while producing electricity.
\end{abstract}

\section{Introduction}

Wastewater treatment using microbial fuel cells (MFCs) is an emerging technology converting organic compounds into electrical energy using microorganisms as biocatalysts [1]. MFC induces simultaneous electrochemical and biochemical reactions that are controlled by characteristics of the microorganisms [2,3]. Though MFC technology is theoretically promising, applications are actually limited by the low power generation [4]. Therefore, improving electricity production of MFC with stable output has been under intense research during the past decade $[5,6]$.

Specifically, the low efficiency of electron transfer through the cell membrane to the anode is a key limiting factor [7]. Indeed, the modification of the anode surface may facilitate the electron transfer as a result of better anode morphology and surface chemistry [8]. Thus, anode materials and modification materials have been developed to enhance power performance. For instance, Liao et al. [9] showed that an anode made of polyaniline-coated carbon cloth modified with tartaric acid enhanced power density 4.1 times compared to the plain carbon cloth anode. Song et al. [10] observed that the surface of graphite modified with $10 \mathrm{mM}$ of anionic surfactant enriched the bacterial attachment compared to $5 \mathrm{mM}$ of surfactant. Hence, anode modification may favor microorganism attachment on the anode surface and, in turn, increase the rate of electron transfer reactions [11]. Since acids and surfactants are charged compounds at suitable $\mathrm{pH}$, this study suggested that the presence of charged organic groups could favor bacterial attachment.

The anode could be improved by having a high biocompatibility, high specific surface area and low-electrode resistance in order to obtain better power generation [12]. MFC anodes have been designed using various modified carbon-based materials for their high biocompatibility and electro-conductivity, such as carbon felt, carbon cloth, carbon paper, carbon fiber, and graphite felt [13], yet anodes made of pure carbon cannot bear higher power density [14]. Alternatively, $\mathrm{Fe}_{3} \mathrm{O}_{4}$ coating appears as suitable anodic modifier due to its good biocompatibility, low cost, high specific surface area, high bacterial affinity and simple synthesis [15]. In addition, $\mathrm{Fe}_{3} \mathrm{O}_{4}$ nanoparticles favor the formation of a multi-layered network by magnetic attraction, and thus accelerate electron transfer [16]. For instance, higher power densities were observed with a carbon paper anode coated with $\mathrm{Fe}_{3} \mathrm{O}_{4}$ /carbon nanotubes (CNT) [17]. Song et al. also assumed that adding $\mathrm{Fe}_{3} \mathrm{O}_{4}$ nano-spheres in graphene anodes may induce excellent bacterial affinity

\footnotetext{
* Corresponding author.

E-mail address: Liuhb@usst.edu.cn (H. Liu).
} 
[18].

Functionalization of $\mathrm{Fe}_{3} \mathrm{O}_{4}$ particles with amino $\left(-\mathrm{NH}_{2}\right)$, sulfhydryl (-SH) and carboxyl (- $\mathrm{COOH})$ groups may also improve energy output by changing surface properties [19-21] and electron transfer [22]. These investigations suggested that the presence of charged groups may improve bacterial attachment and electron transfer. Therefore, this study hypothesized that amino groups, which are protonated at neutral $\mathrm{pH}\left(-\mathrm{NH}_{4}^{+}\right)$could favor the attachment of negatively charged bacteria. To our best knowledge, it has not been determined whether amino-functionalizing $\mathrm{Fe}_{3} \mathrm{O}_{4}$ particle-coated anode was a more favorable electron acceptor than $\mathrm{Fe}_{3} \mathrm{O}_{4}$ particles coated anode in wastewater treatment context. Therefore, this study reported the synthesis of a carbon felt coated with amino-functionalized $\mathrm{Fe}_{3} \mathrm{O}_{4}$ particles and compared its wastewater treatment performances with non-functionalized $\mathrm{Fe}_{3} \mathrm{O}_{4}$.

\section{Materials and methods}

\subsection{Synthesis of $\mathrm{Fe}_{3} \mathrm{O}_{4}$ particles}

The precipitation method was used to prepare $\mathrm{Fe} 3 \mathrm{O} 4$ particles [23]. Typically, a $200 \mathrm{~mL}$ solution was prepared with $0.1 \mathrm{M} \mathrm{FeSO}_{4} \cdot 7 \mathrm{H}_{2} \mathrm{O}$ and $0.1 \mathrm{M} \mathrm{FeCl}_{3} \cdot 6 \mathrm{H}_{2} \mathrm{O} .1 .5 \mathrm{M} \mathrm{NaOH}$ was then added slowly to the solution, magnetically-stirred at $50 \pm 1{ }^{\circ} \mathrm{C}$. When $\mathrm{pH}$ reaches 12.0 , the addition of $\mathrm{NaOHwas}$ stopped and the solution was stirred for $30 \mathrm{~min}$. The formation of $\mathrm{Fe}_{3} \mathrm{O}_{4}$ particles was indicated by a color change from brown (solution) to black (precipitation). The black precipitation solution was water bathed at $80 \pm 1{ }^{\circ} \mathrm{C}$ to allow crystallization within a hour. The black solid precipitation was collected by a magnet and washed repeatedly with distilled water and pure ethanol, then dried at $60^{\circ} \mathrm{C}$ for $12 \mathrm{~h}$. The size of $\mathrm{Fe}_{3} \mathrm{O}_{4}$ particles were roughly identified using Sherrer's equation as $D=K \lambda /(\beta \operatorname{Cos} \theta)$.

\subsection{Synthesis of amino- $\mathrm{Fe}_{3} \mathrm{O}_{4}$ particles}

The synthetic procedure of amino- $\mathrm{Fe}_{3} \mathrm{O}_{4}$ particles was: $0.75 \mathrm{~g}$ of $\mathrm{Fe}_{3} \mathrm{O}_{4}$ particles were dissolved in $100 \mathrm{~mL}$ of a $50 \%$ aqueous acetic acid solution; then the solution $\mathrm{pH}$ was adjusted to 4.0 with anhydrous acetic acid, followed by ultrasonic dispersion for $10 \mathrm{~min}$ at $40 \mathrm{KHz}$ to yield the ferrofluid; $1 \mathrm{~mL}$ 3-aminopropyl triethoxysilane was added to the ferrofluid and purged with dinitrogen gas to remove oxygen [24]. This solution was transferred into a $250 \mathrm{~mL}$ three-neck round-bottom flask, and stirred for $3 \mathrm{~h}$ in a water bath at $60^{\circ} \mathrm{C}$. The product was collected by a magnet and washed successively with distilled water, pure ethanol and anhydrous ether, and dried at $60{ }^{\circ} \mathrm{C}$ for $12 \mathrm{~h}$.

\subsection{Electrode fabrication}

Two carbon felt anodes of $4(\mathrm{~cm}) \times 3(\mathrm{~cm}) \times 0.3(\mathrm{~cm})$, from Beijing Sanye carbon Co., LTD China which were modified by coating. Prior to coating, the carbon felt was cleaned with pure ethanol at room temperature for $12 \mathrm{~h}$, then with concentrated nitric acid at room temperature for $12 \mathrm{~h}$. The treated carbon felt was thoroughly washed with distilled water and dried at $60^{\circ} \mathrm{C}$. The composite was mixed with 0.0080 $\mathrm{g}$ acetylene black, $0.0080 \mathrm{~g}$ polyvinylidenefluoride (PVDF) and $0.0625 \mathrm{~g}$ amino- $\mathrm{Fe}_{3} \mathrm{O}_{4}$ particles or $\mathrm{Fe}_{3} \mathrm{O}_{4}$ particles using $\mathrm{N}$-methyl-2-pyrrolidone (NMP) as dispersant, stirring for $4 \mathrm{~h} \mathrm{[25].} \mathrm{The} \mathrm{composite} \mathrm{was}$ brush-coated onto carbon felt substrates evenly, then dried at $60{ }^{\circ} \mathrm{C}$ under vacuum for $12 \mathrm{~h}$.

\subsection{Configuration and operation of microbial fuel cells}

Two $150 \mathrm{~mL}$ MFC batteries made of plexiglass were coupled into a dual-chamber MFC configuration [26], one battery with a $\mathrm{Fe}_{3} \mathrm{O}_{4}$-coated carbon felt anode and the other with an amino- $\mathrm{Fe}_{3} \mathrm{O}_{4}$-coated carbon felt anode. Both batteries use $4(\mathrm{~cm}) \times 3(\mathrm{~cm}) \times 0.005(\mathrm{~cm})$ stainless steel mesh from China Pingzhen Hardware Wire Mesh Co., Ltd. as the cathode. In the anode chamber, $60 \mathrm{~mL}$ synthetic domestic wastewater or $60 \mathrm{~mL}$ anaerobic sludge were used as anolyte and stirred by a magnetic stirrer. The sludge concentration in the anode chamber was about 3980-4150 $\mathrm{mg} / \mathrm{L}$. In the cathode chamber, $120 \mathrm{~mL} 0.1 \mathrm{M}$ phosphate buffer solution (PBS) was used as catholyte and aerated continuously. The anode chamber and cathode chambers were separated by a $16 \mathrm{~cm}^{2}$ of proton exchange membrane (PEM) Nafion 117, as described by Liu et al. [27]. The distance between the anode and the cathode was $6 \mathrm{~cm}$; the anode and cathode were connected with an external load external resistance $(1000 \Omega)$. All experiments were performed at room temperature of $25-35{ }^{\circ} \mathrm{C}$.

The anaerobic sludge originates from the Shanghai Eastern District wastewater plant. At the start-up phase, the synthetic wastewater had a chemical oxygen demand (COD) of $500 \mathrm{mg} / \mathrm{L}$, ammonium $\left(\mathrm{NH}_{4}^{+}-\mathrm{N}\right)$ of $15 \mathrm{mg} / \mathrm{L}$, total phosphorus (TP) of $5 \mathrm{mg} / \mathrm{L}$, and contained per $\mathrm{L}$ of distilled water: $0.253 \mathrm{~g}$ glucose, $0.583 \mathrm{~g} \mathrm{C}_{2} \mathrm{H}_{3} \mathrm{NaO}_{2} \cdot 3 \mathrm{H}_{2} \mathrm{O}, 0.110 \mathrm{~g}$ $\mathrm{NH}_{4} \mathrm{Cl}, 0.022 \mathrm{~g} \mathrm{KH}_{2} \mathrm{PO}_{4}, 0.005 \mathrm{~g} \mathrm{MgSO}_{4} \cdot \mathrm{H}_{2} \mathrm{O}, 0.055 \mathrm{~g} \mathrm{NaHCO}_{3}, 2 \mathrm{~mL}$ trace elements and $2 \mathrm{~mL} 0.1 \mathrm{M}$ phosphate buffer solution (PBS). The composition of trace elements (mass of trace elements per liter) are as follows: $0.900 \mathrm{~g} \mathrm{FeCl}_{3}, 0.120 \mathrm{~g} \mathrm{ZnSO}_{4} \cdot 7 \mathrm{H}_{2} \mathrm{O}, 0.060 \mathrm{~g} \mathrm{Na}_{2} \mathrm{MoSO}_{4} \cdot 2 \mathrm{H}_{2} \mathrm{O}$, $0.060 \mathrm{~g} \mathrm{MnCl} \cdot 4 \mathrm{H}_{2} \mathrm{O}, 0.180 \mathrm{~g} \mathrm{KI}, 0.03 \mathrm{~g} \mathrm{CuSO}_{4} \cdot 5 \mathrm{H}_{2} \mathrm{O}, 0.150 \mathrm{~g}$ $\mathrm{CaCl}_{2} \cdot 6 \mathrm{H}_{2} \mathrm{O}$ and $0.150 \mathrm{~g} \mathrm{H}_{3} \mathrm{BO}_{3}$. The phosphate buffer solution (PBS) contained per liter (L) of distilled water: $8 \mathrm{~g} \mathrm{NaCl}, 0.2 \mathrm{~g} \mathrm{KCl}, 0.2 \mathrm{~g}$ $\mathrm{KH}_{2} \mathrm{PO}_{4}$, and $2.9 \mathrm{~g} \mathrm{Na}_{2} \mathrm{HPO}_{4} \cdot 12 \mathrm{H}_{2} \mathrm{O}$. At the operational phase, the water distribution concentration of the anolyte contained COD of $1000 \mathrm{mg} / \mathrm{L}$, $\mathrm{NH}_{4}^{+}-\mathrm{N}$ of $30 \mathrm{mg} / \mathrm{L}$ and $\mathrm{TP}$ of $10 \mathrm{mg} / \mathrm{L}$, that is twice compared to the start-up phase, while the operating parameters of the catholyte remained unchanged.

\subsection{Analytical techniques and characterization}

Cell voltages were recorded every minute by a digital multi-meter from PicoLog Technology, UK. The power density and polarization curve of the MFC were obtained by varying the external resistance from 100 to $100,000 \Omega$ with stable voltages. The power densities $\mathrm{P}$ in $\mathrm{mW} / \mathrm{m}^{2}$ were calculated using the $P=U I$ equation(U is voltage, I is electric current). Liquid samples were taken from the supernatant at each operational cycle and measured after filtration. $\mathrm{COD}, \mathrm{NH}_{4}^{+}-\mathrm{N}$, nitrate $\left(\mathrm{NO}_{3}^{-}-\mathrm{N}\right)$ and nitrite $\left(\mathrm{NO}_{2}^{-}-\mathrm{N}\right)$ were measured according to standard methods from APHA [28]. Dissolved oxygen (DO) was measured with a dissolved oxygen meter from JPB-607, Leici, China.

Cyclic voltammetry (CV) and electrochemical impedance spectroscopy (EIS) of the anode were measured by the electrochemical workstation CHI660E, Chenhua, China, in a single chamber with the working electrode (anode), a counter Pt electrode and a reference electrode made of $\mathrm{Ag} / \mathrm{AgCl}$ and saturated $\mathrm{KCl}$. The $\mathrm{CV}$ test was done from $-0.3 \mathrm{~V}$ to $0.6 \mathrm{~V}$ at a scanning rate of $10 \mathrm{mV} / \mathrm{s}$. EIS analysis was measured from $100 \mathrm{kHz}$ to $700 \mathrm{kHz}$ in an open circuit. The synthetic $\mathrm{Fe}_{3} \mathrm{O}_{4}$ particles and amino$\mathrm{Fe}_{3} \mathrm{O}_{4}$ particles were characterized by X-ray diffraction (XRD) using a D8-Advance from Germany, and by Fourier transform infrared spectroscopy (FTIR) from ThermoFisher Scientific, Germany; the surface morphology of the biofilm on anodes was carried out by scanning electron microscopy (SEM) from Carl Zeiss EVO LS10, UK.

\section{Results and discussion}

\subsection{Characterization of $\mathrm{Fe}_{3} \mathrm{O}_{4}$ and amino- $\mathrm{Fe}_{3} \mathrm{O}_{4}$ coatings}

This study investigated the structure, properties and power generation of MFC made of carbon felt anodes coated with either $\mathrm{Fe}_{3} \mathrm{O}_{4}$ or amino- $\mathrm{Fe}_{3} \mathrm{O}_{4}$. XRD patterns of amino- $\mathrm{Fe}_{3} \mathrm{O}_{4}$ particles and $\mathrm{Fe}_{3} \mathrm{O}_{4}$ particles were illustrated with Fig. 1a. Results showed that both amino- $\mathrm{Fe}_{3} \mathrm{O}_{4}$ and $\mathrm{Fe}_{3} \mathrm{O}_{4}$ particles show identical diffraction peaks typical of magnetite $\mathrm{Fe}_{3} \mathrm{O}_{4}$ (PDF No.75-0449), at $30.647^{\circ}, 35.473^{\circ}, 43.277^{\circ}, 54.155^{\circ}$, $57.050^{\circ}$ and $62.667^{\circ}$, corresponding to (220), (311), (400), (422), (511) 

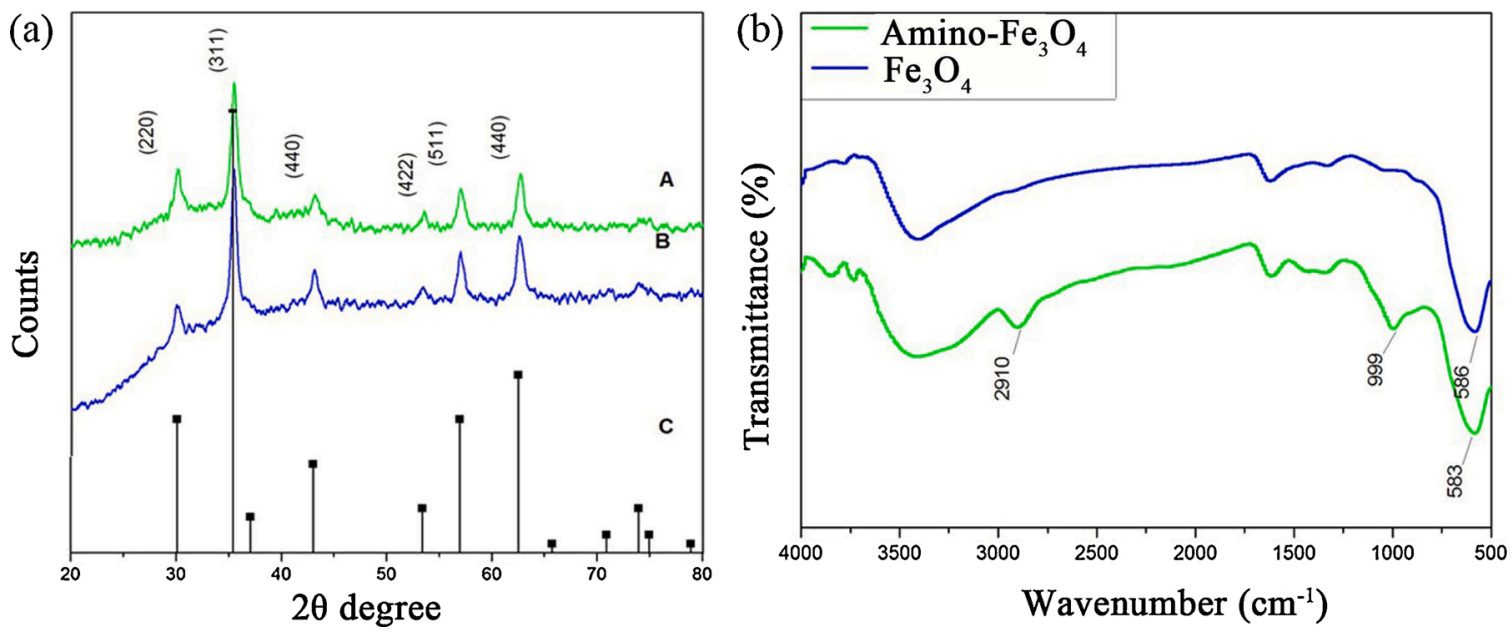

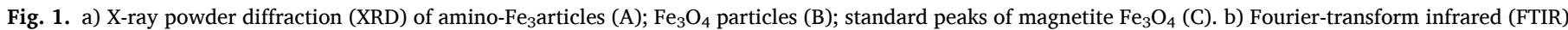
spectra of $\mathrm{Fe}_{3} \mathrm{O}_{4}$ particles and amino- $\mathrm{Fe}_{3} \mathrm{O}_{4}$ particles.

and (440) crystal face of $\mathrm{Fe}_{3} \mathrm{O}_{4}$, respectively [29]. Calculation results of Sherrer's equation $(D=K \lambda /(\beta \operatorname{Cos} \theta))$ indicated that the size was $15 \mathrm{~nm}$ both for amino- $\mathrm{Fe}_{3} \mathrm{O}_{4}$ particles and $\mathrm{Fe}_{3} \mathrm{O}_{4}$ particles. Overall, $\mathrm{Fe}_{3} \mathrm{O}_{4}$ particles modified with amino keep original physical properties.

Fig. 1b showed the FT-IR spectra of amino- $\mathrm{Fe}_{3} \mathrm{O}_{4}$ particles and $\mathrm{Fe}_{3} \mathrm{O}_{4}$ particles. The peak at $565 \mathrm{~cm}^{-1}$ corresponds to $\mathrm{Fe}-\mathrm{O}$ bonds in the spectra of amino- $\mathrm{Fe}_{3} \mathrm{O}_{4}$ particles and $\mathrm{Fe}_{3} \mathrm{O}_{4}$ particles [24]. The broad bands at $999 \mathrm{~cm}^{-1}$ and $2910 \mathrm{~cm}^{-1}$ are ascribed to Si-O-Si groups and $\mathrm{NH}$ stretching vibration of the grafted amino material, respectively [30,31]. Therefore, $\mathrm{Si}-\mathrm{O}$ groups and $\mathrm{NH}$ bonds confirm the successful addition of amino group to the surface of $\mathrm{Fe}_{3} \mathrm{O}_{4}$ particles.

Composition, structure and performance of the surface amino modification $\mathrm{Fe}_{3} \mathrm{O}_{4}$ particles indicated that the particle size of the magnetic particles after the surface amination was slightly increased, with better adsorption performance and better retention capacity than the original magnetic features. The results implied that MFC with aminofunctionalized $\mathrm{Fe}_{3} \mathrm{O}_{4}$ as anode can better bind and fix the load with biomolecules in sewage, which makes MFC generate stronger current so as to achieve better sewage treatment efficiency.

\subsection{Performance of microbial fuel cells}

\subsubsection{Performances of start up and operational runs}

Fig. 2 depicted the voltage profiles during the start-up and operational stages of MFC using the amino- $\mathrm{Fe}_{3} \mathrm{O}_{4}$ and the $\mathrm{Fe}_{3} \mathrm{O}_{4}$ coated anodes. Inoculate and adapt the anode in MFCs containing standard Pt/ C carbon felt anodes, using an external resistance of $1000 \Omega$, the voltage generated by MFC at this time was in a stable and easy-to-detect working state, which had good reference and practicality. Results showed that both anodes yield repeatable voltages of $530 \pm 10 \mathrm{mV}$ with $1000 \Omega$ external resistors after successful start-up. The output voltage of the reactor was lower than the reactor with amino- $\mathrm{Fe}_{3} \mathrm{O}_{4}$ anode about 350 $\mathrm{mV}$ using $\mathrm{Fe}_{3} \mathrm{O}_{4}$ anode in the first five days; then it reached $520 \mathrm{mV}$ after the fifth day, at which time the maximum output voltage was closer to the amino- $\mathrm{Fe}_{3} \mathrm{O}_{4}$ anode reactor (Fig. 2a). Using the amino- $\mathrm{Fe}_{3} \mathrm{O}_{4}$ anode, voltage output of the reactor rose to $520 \mathrm{mV}$ after $12 \mathrm{~h}$, then reached a maximum voltage about $620 \mathrm{mV}$ after 5 days. The output voltage cycle of the reactor using $\mathrm{Fe}_{3} \mathrm{O}_{4}$ anode was the same as the output voltage cycle of the amino- $\mathrm{Fe}_{3} \mathrm{O}_{4}$ anode reactor, but the output voltage was always lower than that of the amino- $\mathrm{Fe}_{3} \mathrm{O}_{4}$ anode reactor, which showed that the amino- $\mathrm{Fe}_{3} \mathrm{O}_{4}$ anode had better and more stable power generation performance (Fig. 2b).

The start-up time of the amino- $\mathrm{Fe}_{3} \mathrm{O}_{4}$ anode was much faster than the $\mathrm{Fe}_{3} \mathrm{O}_{4}$ anode (left arrow in Fig. 2a). This finding implied that amino groups set more rapidly a bacterial-electrode system that favors electron transfer. This acceleration effect was supported by findings of Jiang et al. who observed that the start-up time of a MFC system with a carbon cloth anode covered by polypyrrole, a polymer containing aromatic - NHgroups, was lower than that of the plain carbon cloth anode [32]. Therefore, this study implies that amino groups create positive charges (a)

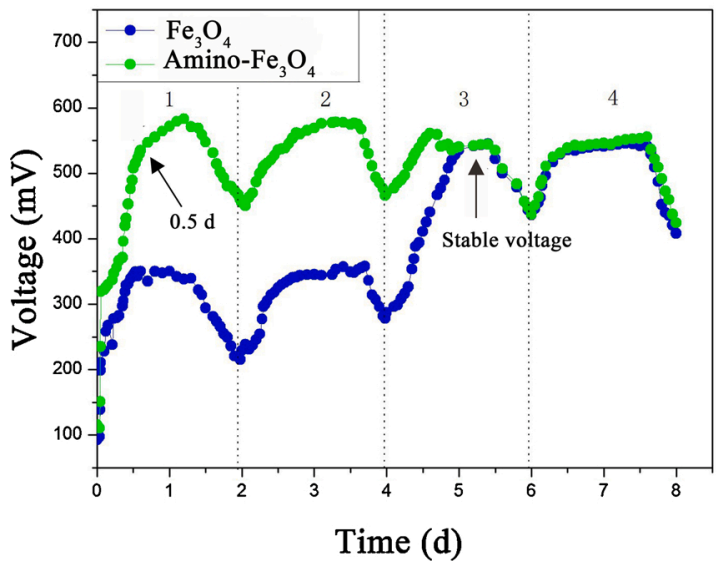

(b)

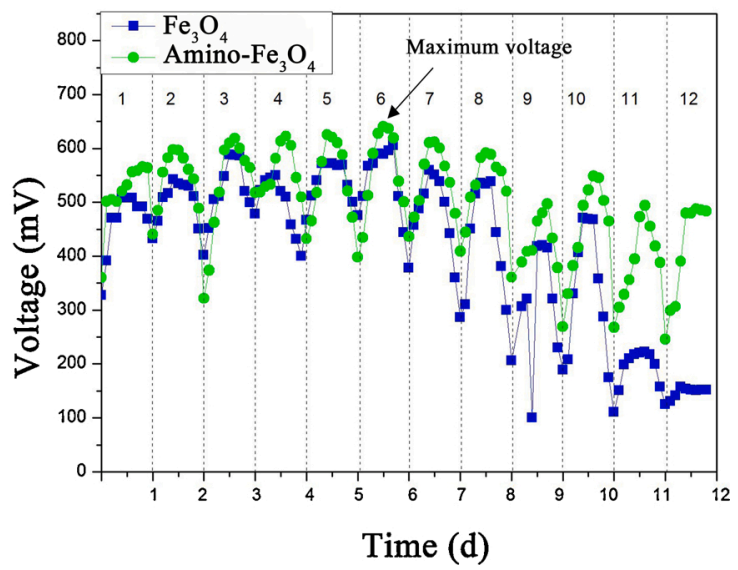

Fig. 2. Voltage of microbial fuel cells equipped with $\mathrm{Fe} 3 \mathrm{O} 4$ and amino-Fe3O4 coated anodes. Start-up voltage (a) and operational voltage (b). 
on the anode surface and, in turn, increase the adhesion rate of negatively charged bacteria.

Fig. $2 \mathrm{~b}$ showed the operational voltage generated within 12 days. Results showed that the maximum voltage generation was higher, of 641 $\mathrm{mV}$, using the amino- $\mathrm{Fe}_{3} \mathrm{O}_{4}$ anode, than for the $\mathrm{Fe}_{3} \mathrm{O}_{4}$ anode of $589 \mathrm{mV}$. After 6 cycles, the voltage generation started to drop, though less rapidly for the amino- $\mathrm{Fe}_{3} \mathrm{O}_{4}$ anode, which displays better stability. The voltage drop could be explained by microbial inhibition following addition of external substrate, and by limited energy required for microbial growth [33]. As a consequence, the higher mass transfer and ohmic resistances limited the diffusion of protons and electrons, which decrease the output voltage. Overall, the findings of this study show that the amino- $\mathrm{Fe}_{3} \mathrm{O}_{4}$ anode induces a higher and more stable voltage output, which could be explained by easier bacterial attachment to protonated amino groups.

\subsubsection{Power density}

Power output and power density curves of the study wastewater treatment MFC were illustrated in Fig. 3. Current generation showed a decreasing trend with increase in the resistance along with lower potential drop. Using the polarization curve in Fig. 3a, the amino- $\mathrm{Fe}_{3} \mathrm{O}_{4}$ anode cell had a lower internal resistance than for the $\mathrm{Fe}_{3} \mathrm{O}_{4}$ anode cell. The power density curves showed that the maximum power density using the amino- $\mathrm{Fe}_{3} \mathrm{O}_{4}$ anode, of $208.67 \mathrm{~mW} / \mathrm{m}^{2}$, was $35.1 \%$ higher than that of the $\mathrm{Fe}_{3} \mathrm{O}_{4}$ anode, as $154.41 \mathrm{~mW} / \mathrm{m}^{2}$ (Fig. 3b). The observation strengthens the previous finding, which suggested that modifying $\mathrm{Fe}_{3} \mathrm{O}_{4}$ anode with amino groups improves power generation. This increase of power density was also in line with power density increases observed following the modification of carbon nanotubes and carbon cloth. The findings demonstrated that the addition of amino groups on the $\mathrm{Fe}_{3} \mathrm{O}_{4}$ coated carbon felt enhances electron transfer and power output.

\subsubsection{Wastewater treatment}

Fig. 4a depicted the chemical oxygen demand (COD) of the influent and effluent of two microbial fuel cells (amino- $\mathrm{Fe}_{3} \mathrm{O}_{4}$-NPs MFC and $\mathrm{Fe}_{3} \mathrm{O}_{4}$ MFC) during the stable operation period. Under the same operating conditions and working conditions, compare the COD removal effects of the amino- $\mathrm{Fe}_{3} \mathrm{O}_{4}$-NPs MFC and $\mathrm{Fe}_{3} \mathrm{O}_{4}$ MFC devices. Among them, $\mathrm{Fe}_{3} \mathrm{O}_{4}$ MFC was the MFC with $\mathrm{Fe}_{3} \mathrm{O}_{4}$ activated carbon felt as the anode material. $\mathrm{Fe}_{3} \mathrm{O}_{4}$ nanoparticles facilitate the formation of a multilayer network through magnetic attraction, thereby accelerate electron transfer [16]. Results showed that, the average COD removal efficiency using amino- $\mathrm{Fe}_{3} \mathrm{O}_{4}$ coated anode and $\mathrm{Fe}_{3} \mathrm{O}_{4}$ coated anode are similar during one operational cycle, of $91.5 \%$ and $90.8 \%$ respectively. This absence of difference could be explained by the fact that the carbon sources, glucose and sodium acetateare rapidly degraded in the anode chamber, thus rapidly reach the degradation limit, which is very helpful to confirm hypothesis of a previous finding [34].

This study further investigated the removal efficiency of $\mathrm{NH}_{4}^{+}-\mathrm{N}$. Fig. $4 \mathrm{~b}$ showed the concentration of $\mathrm{NH}_{4}^{+}-\mathrm{N}, \mathrm{NO}_{3}^{-}-\mathrm{N}$ and $\mathrm{NO}_{2}^{-}-\mathrm{N}$ in the anolyte and catholyte of the cells. Results show that the influent $\mathrm{NH}_{4}^{+}-\mathrm{N}$ concentrations for amino- $\mathrm{Fe}_{3} \mathrm{O}_{4}$ anode MFC, of $26.87 \mathrm{mg} / \mathrm{L}$, was lower than that of the $\mathrm{Fe}_{3} \mathrm{O}_{4}$ anode cell, of $29.10 \mathrm{mg} / \mathrm{L}$. During one operational cycle, the average $\mathrm{NH}_{4}^{+}-\mathrm{N}$ removal efficiency reached $97.7 \%$ using the amino- $\mathrm{Fe}_{3} \mathrm{O}_{4}$ anode, versus $48.9 \%$ for the $\mathrm{Fe}_{3} \mathrm{O}_{4}$-coated anode. The results also show that in the amino $\mathrm{Fe}_{3} \mathrm{O}_{4} \mathrm{MFC}, \mathrm{NO}_{3}^{-}-\mathrm{N}$ is almost the only form of $\mathrm{N}$; while in the $\mathrm{Fe}_{3} \mathrm{O}_{4}$ anode MFC, the ratio of $\mathrm{NO}_{3}^{-}-\mathrm{N}$ to $\mathrm{NH}_{4}^{-}-\mathrm{N}$ is similar.

These findings suggested a much higher biological nitrification using the amino- $\mathrm{Fe}_{3} \mathrm{O}_{4}$ anode. In a similar way, ammonia loss of the singlechambered MFC had been explained by volatilization due to $\mathrm{pH}$ increase at the cathode surface, by biological nitrification and denitrification [35] and by nitrification through air cathodes [36]. In the amino- $\mathrm{Fe}_{3} \mathrm{O}_{4} \mathrm{MFC}$, a part of $\mathrm{NH}_{4}^{+}-\mathrm{N}$ reached anolyte through the proton exchange membrane, and then transformed to $\mathrm{NO}_{3}^{-}-\mathrm{N}$ in the presence of dioxygen. This finding reinforced hypothesis of the study by which protonated amino groups favor the attachment of bacteria that is in line with studies on amino functionalization of other materials [37]. The results show that the nitrification efficiency for amino- $\mathrm{Fe}_{3} \mathrm{O}_{4}$ anode MFC was much higher than that of $\mathrm{Fe}_{3} \mathrm{O}_{4}$ anode MFC.

\subsection{Electrochemical performance of electrodes}

$\mathrm{CV}$ measurement for the fabricated anodes was performed in the solution of $0.1 \mathrm{M}$ potassium ferricyanide (Fig. 5a). Results showed that the amino- $\mathrm{Fe}_{3} \mathrm{O}_{4}$ coated anode induced a much higher current response and redox reversibility than for the $\mathrm{Fe}_{3} \mathrm{O}_{4}$ coated anode. In addition, both coated anodes showed higher current responses versus the bare carbon anode. These findings were explained by the higher conductivity of $\mathrm{Fe}_{3} \mathrm{O}_{4}$ versus other materials. Moreover, the results confirmed that the addition of amino groups favors the involvement of electrochemically active bacteria, strengthens the hypothesis of bacterial attachment to the anode by positive-negative charge attraction.

EIS measurement for the fabricated anodes was performed in the solution of $0.1 \mathrm{M}$ potassium ferricyanide (Fig. 5b). Results showed that the semicircle of $\mathrm{Fe}_{3} \mathrm{O}_{4}$ coated anode was larger than that of the amino$\mathrm{Fe}_{3} \mathrm{O}_{4}$ coated anode. In a typical Nyquist plot, the diameter of a semicircle yields the charge-transfer resistance which represented the resistance of electrochemical reactions at the electrode [38]. The finding revealed that interfacial charge-transfer resistance of the amino- $\mathrm{Fe}_{3} \mathrm{O}_{4}$ coated anode, of $26 \Omega / \mathrm{cm}^{2}$, was lower than that of the $\mathrm{Fe}_{3} \mathrm{O}_{4}$ coated anode, of $34 \Omega / \mathrm{cm}^{2}$. This lower resistance confirmed again the higher (a)

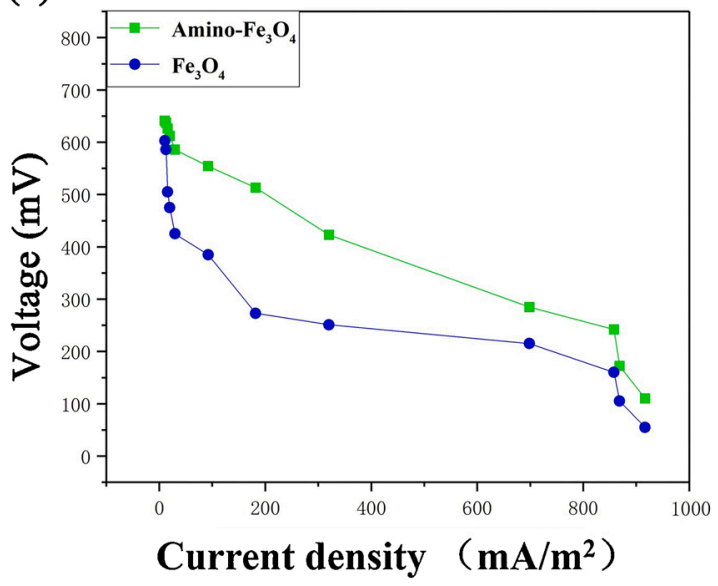

(b)

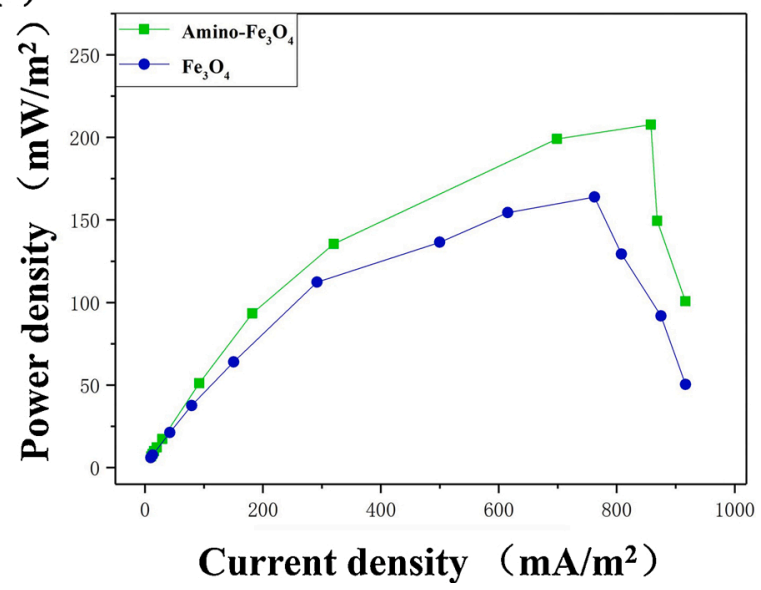

Fig. 3. Polarization (a) and power density curves (b) of microbial fuel cells (MFC) with the amino- $\mathrm{Fe}_{3} \mathrm{O}_{4}$ coated anode and the Fe $\mathrm{O}_{4}$ coated anode. 
(a)

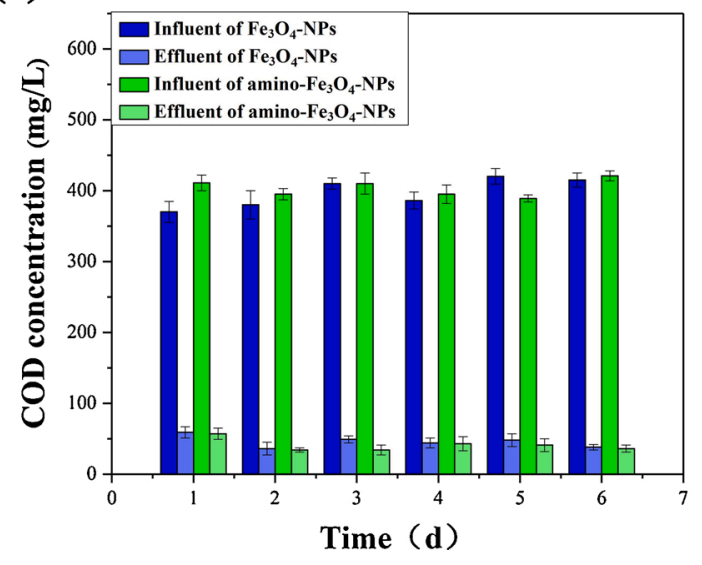

(b)

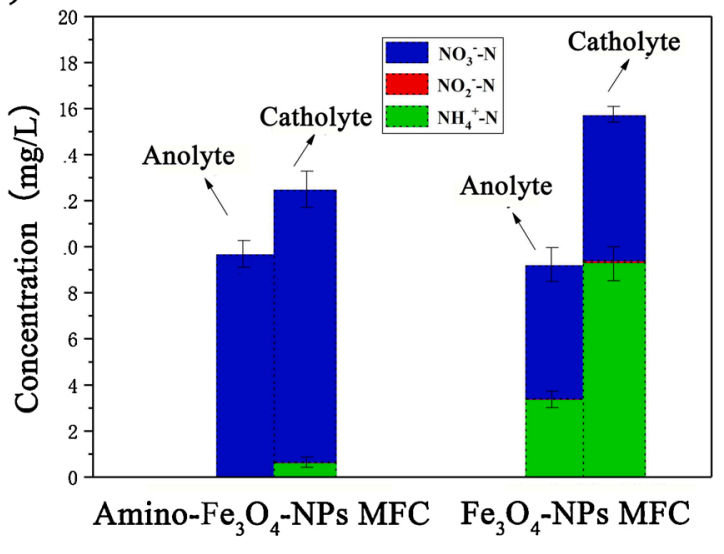

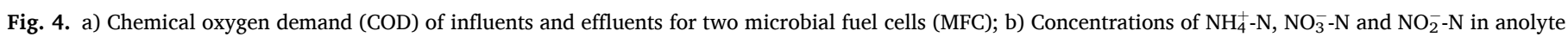
and catholyte of two cells.
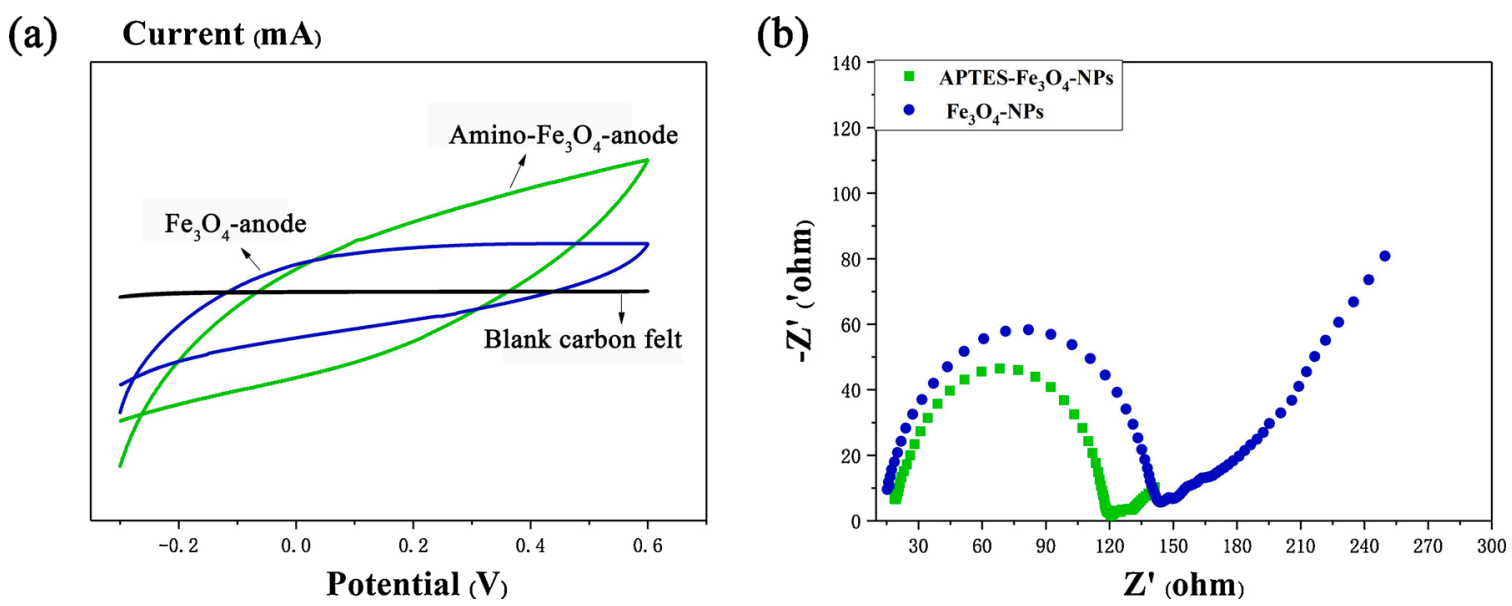

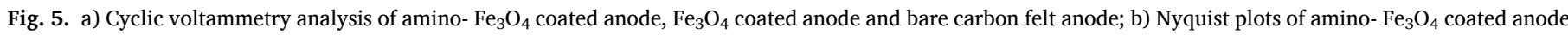
and $\mathrm{Fe}_{3} \mathrm{O}_{4}$ coated anode.

electrical performance of the amino- $\mathrm{Fe}_{3} \mathrm{O}_{4}$ coated anode.

Fig. 6 showed the anode biofilms after two months of operation visually and by scanning electron microscopy. Results demonstrate that more activated sludge was attached on the surface of the amino- $\mathrm{Fe}_{3} \mathrm{O}_{4}$ coated anode than on the $\mathrm{Fe}_{3} \mathrm{O}_{4}$ coated anode. Fig. 6(a) was an SEM image of the biofilm on the anode coated with $\mathrm{Fe}_{3} \mathrm{O}_{4}$; Fig. 6(b) was an
SEM image of the biofilm on the anode coated with $\mathrm{Fe}_{3} \mathrm{O}_{4}$. Through comparison, it was found that the aminated $\mathrm{Fe}_{3} \mathrm{O}_{4}$ coated anode had a larger specific surface area and a multi-layer complex structure. Such a structure was conducive to the formation and attachment of biofilm on its surface. The comparison of the biofilm adsorbed substances and biological sludge on the image was also confirmed. This conjecture

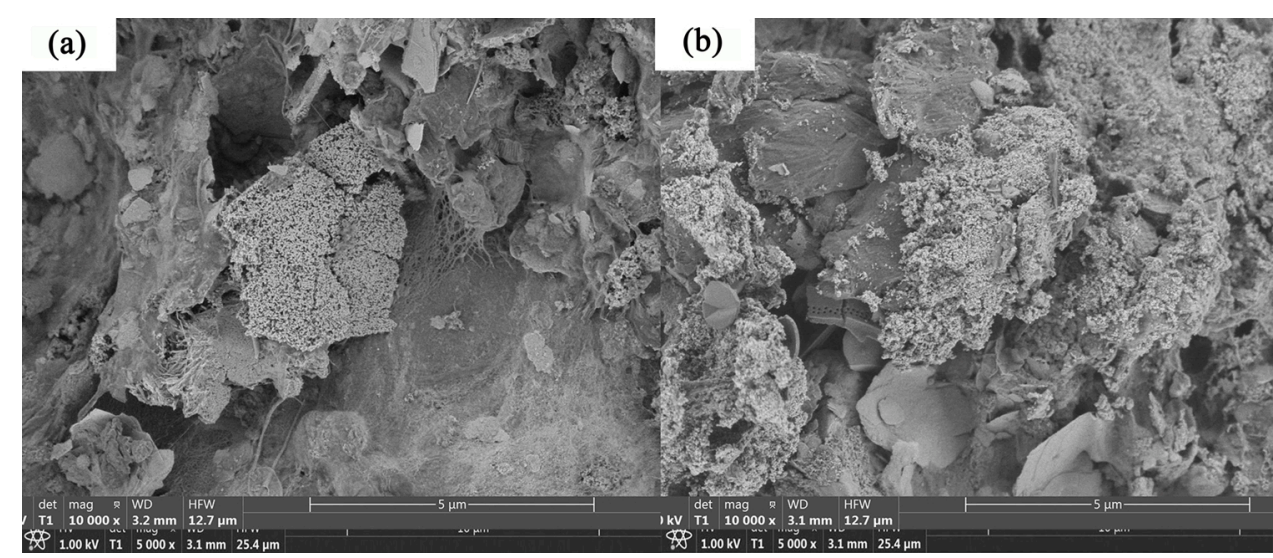

Fig. 6. Images of biofilm on anodes after one month of operation: (a) SEM images of biofilm on the $\mathrm{Fe}_{3} \mathrm{O}_{4}$ coated anode; (b) SEM images of biofilm on the amino$\mathrm{Fe}_{3} \mathrm{O}_{4}$ coated anode. 
showed that the modification of the surface of the electrode by the amino $\mathrm{Fe}_{3} \mathrm{O}_{4}$ coating was positive, which would optimize the electrochemical performance of the MFC and remove sewage pollutants.

The materials used for experimental testing were mainly used as anode materials in the MFC experimental device. In the process of sewage treatment, biofilms were formed near the anode and cathode materials of the MFC. The microorganisms in the biofilms adsorb and degrade pollutants in the sewage. Therefore, after the device had been operating stably for a period of time, we took out the carbon felt anode coated with amino functionalized $\mathrm{Fe}_{3} \mathrm{O}_{4}$ without cleaning it, and keep the microorganisms attached to the carbon felt for direct detection. According to related information and experimental practice, the carbon felt anode coated with amino-functionalized $\mathrm{Fe}_{3} \mathrm{O}_{4}$ had a larger particle pore size than the carbon felt anode coated with $\mathrm{Fe}_{3} \mathrm{O}_{4}$ and ordinary carbon felt anode, which was conducive to the attachment of more microorganisms. The micro-currents formed between MFCs promote each other and had a better treatment effect.

Overall, the results of this study indicate that the increase in the surface area of the $\mathrm{Fe}_{3} \mathrm{O}_{4}$ anode modified with amino groups is more conducive to the attachment of bacterial flora on the anode surface, which induces a higher and more stable voltage output and enhances the electron transfer of the system. The amino-modified $\mathrm{Fe}_{3} \mathrm{O}_{4}$ anode is combined with a microbial fuel cell using high electron transfer capacity. Since amino-functional polymer magnetic electrodes could also act as adsorbent media [39], bio-adsorption process could be another contributor to better performance of this study.

\section{Conclusions}

The size of the magnetic particles did not change after surface amination, and the particle size increases slightly, which had better adsorption performance and better retention than the original magnetic characteristics. The output voltage of the amino- $\mathrm{Fe}_{3} \mathrm{O}_{4}$ anode reactor increased to $520 \mathrm{mV}$ after $12 \mathrm{~h}$, and reached a maximum voltage of about $620 \mathrm{mV}$ and a maximum power density of $208.67 \mathrm{~mW} / \mathrm{m}^{2}$ after 5 days. This data was far better than $\mathrm{Fe}_{3} \mathrm{O}_{4}$ anode reactor. This finding indicated that the amino group can quickly establish a bacterial electrode system and promote electron transfer.

COD removal efficiency of the amino $\mathrm{Fe}_{3} \mathrm{O}_{4}$ coated anode and the $\mathrm{Fe}_{3} \mathrm{O}_{4}$ coated anode were simila, which indicates that in the amino$\mathrm{Fe}_{3} \mathrm{O}_{4}$ MFC, a part of $\mathrm{NH}_{4}^{+}-\mathrm{N}$ reached the anolyte through the proton exchange membrane, and then was converted into $\mathrm{NO}_{3}^{-}-\mathrm{N}$ in the presence of hydrogen peroxide. This finding reinforced the hypothesis of this study that protonated amino groups were beneficial to bacterial attachment, which was consistent with the functionalization of amino groups.

\section{Declaration of Competing Interest}

The authors have declared no conflict of interest.

\section{Acknowledgements}

This study was supported by the National Key Research and Development Program of China (2018YFD1100502-01) and the Bill \& Melinda Gates Foundation, Seattle, WA (RTTC-China 2014).

\section{References}

[1] B.E. Logan, K. Rabaey, Conversion of wastes into bioelectricity and chemicals by using microbial electrochemical technologies, Science 337 (2012) 686-690.

[2] T. Zhang, Y. Zeng, S. Chen, X. Ai, H. Yang, Improved performances of E. Colicatalyzed microbial fuel cells with composite graphite/PTFE anodes, Electrochem. Commun. 9 (2007) 349-353.

[3] H. Liu, F. Leng, Y. Guan, Y. Yao, Y. Li, S. Xu, Simultaneous pollutant removal and electricity generation in a combined ABR-MFC-MEC system treating fecal wastewater, Water Air Soil Pollut. 228 (2017) 179.
[4] Z. He, S.D. Minteer, L.T. Angenent, Electricity generation from artificial wastewater using an upflow microbial fuel cell, Environ. Sci. Technol. 39 (2005) 5262-5267.

[5] I. Gajda, J. Greenman, C. Melhuish, I. Ieropoulos, Self-sustainable electricity production from algae grown in a microbial fuel cell system, Biomass Bioenergy 82 (2015) 87-93.

[6] X. Guo, Y. Zhan, C. Chen, B. Cai, Y. Wang, S. Guo, Influence of packing material characteristics on the performance of microbial fuel cells using petroleum refinery wastewater as fuel, Renew. Energy 87 (2016) 437-444.

[7] R. Kumar, L. Singh, A. Zularisam, Exoelectrogens: recent advances in molecular drivers involved in extracellular electron transfer and strategies used to improve it for microbial fuel cell applications, Renew. Sustain. Energy Rev. 56 (2016) $1322-1336$.

[8] P. Choudhury, U.S. Prasad Uday, T.K. Bandyopadhyay, R.N. Ray, B. Bhunia, Performance improvement of microbial fuel cell (MFC) using suitable electrode and Bioengineered organisms: a review, Bioengineered 8 (2017) 471-487.

[9] Z.-H. Liao, J.-Z. Sun, D.-Z. Sun, R.-W. Si, Y.-C. Yong, Enhancement of power production with tartaric acid doped polyaniline nanowire network modified anode in microbial fuel cells, Bioresour. Technol. 192 (2015) 831-834.

[10] Y.C. Song, D.S. Kim, J.H. Woo, B. Subha, S.H. Jang, S. Sivakumar, Effect of surface modification of anode with surfactant on the performance of microbial fuel cell, Int. J. Energy Res. 39 (2015) 860-868.

[11] H.-Y. Wang, A. Bernarda, C.-Y. Huang, D.-J. Lee, J.-S. Chang, Micro-sized microbial fuel cell: a mini-review, Bioresour. Technol. 102 (2011) 235-243.

[12] V.J. Watson, C. Nieto Delgado, B.E. Logan, Influence of chemical and physical properties of activated carbon powders on oxygen reduction and microbial fuel cell performance, Environ. Sci. Technol. 47 (2013) 6704-6710.

[13] Mu C.-P.-B. Siu, et al., A microfabricated PDMS microbial fuel cell, J. Microelectromechanical Syst. (2008).

[14] A. Mehdinia, E. Ziaei, A. Jabbari, Multi-walled carbon nanotube/SnO2 nanocomposite: a novel anode material for microbial fuel cells, Electrochim. Acta 130 (2014) 512-518.

[15] J. Sun, S. Zhou, P. Hou, Y. Yang, J. Weng, X. Li, M. Li, Synthesis and characterization of biocompatible Fe3O4 nanoparticles, J. Biomed. Mater. Res., Part A 80 (2007) 333-341.

[16] X. Peng, H. Yu, X. Wang, Q. Zhou, S. Zhang, L. Geng, J. Sun, Z. Cai, Enhanced performance and capacitance behavior of anode by rolling Fe3O4 into activated carbon in microbial fuel cells, Bioresour. Technol. 121 (2012) 450-453.

[17] I.H. Park, M. Christy, P. Kim, K.S. Nahm, Enhanced electrical contact of microbes using Fe3O4/CNT nanocomposite anode in mediator-less microbial fuel cell, Biosens. Bioelectron. 58 (2014) 75-80.

[18] R.-B. Song, C.-E. Zhao, L.-P. Jiang, E.S. Abdel-Halim, J.-R. Zhang, J.-J. Zhu, Bacteria-affinity 3D macroporous graphene/MWCNTs/Fe3O4 foams for highperformance microbial fuel cells, ACS Appl. Mater. Interfaces 8 (2016) $16170-16177$.

[19] C. Meng, W. Zhikun, L. Qiang, L. Chunling, S. Shuangqing, H. Songqing, Preparation of amino-functionalized Fe304@mSiO2 core-shell magnetic nanoparticles and their application for aqueous Fe3+ removal, J. Hazard. Mater. 341 (2018) 198-206.

[20] Z. Shi, C. Xu, P. Lu, L. Fan, Y. Liu, Y. Wang, L. Liu, L. Li, Preparation and the adsorption ability of thiolated magnetic core-shell Fe3O4@SiO2@ C-SH for removing Hg2+ in water solution, Mater. Lett. 225 (2018) 130-133.

[21] T.T. Luong, T.P. Ha, L. Dai Tran, M.H. Do, T.T. Mai, N.H. Pham, H.B.T. Phan, G.H. T. Pham, N.M.T. Hoang, Q.T. Nguyen, Design of carboxylated Fe304/poly (styrene-co-acrylic acid) ferrofluids with highly efficient magnetic heating effect, Colloids Surf. Physicochem. Eng. Asp. 384 (2011) 23-30.

[22] T. Saito, M. Mehanna, X. Wang, R.D. Cusick, Y. Feng, M.A. Hickner, B.E. Logan, Effect of nitrogen addition on the performance of microbial fuel cell anodes, Bioresour. Technol. 102 (2011) 395-398.

[23] Q. Yang, L.I. Fengyan, F. Qiu, Y. Liu, S.O. Textiles, T.P. University, Preparation and characterization of Fe_30_4 nano particles with oxygen, J. Text. Res. (2016) (In Chinese).

[24] M. Yamaura, R. Camilo, L. Sampaio, M. Macedo, M. Nakamura, H. Toma, Preparation and characterization of (3-aminopropyl) triethoxysilane-coated magnetite nanoparticles, J. Magn. Magn. Mater. 279 (2004) 210-217.

[25] P. Hao, Z. Zhao, J. Tian, H. Li, Y. Sang, G. Yu, H. Cai, H. Liu, C. Wong, A. Umar, Hierarchical porous carbon aerogel derived from bagasse for high performance supercapacitor electrode, Nanoscale 6 (2014) 12120-12129.

[26] Y. Fan, H. Hu, H. Liu, Enhanced Coulombic efficiency and power density of aircathode microbial fuel cells with an improved cell configuration, J. Power Sources 171 (2007) 348-354.

[27] H. Liu, B.E. Logan, Electricity generation using an air-cathode single chamber microbial fuel cell in the presence and absence of a proton exchange membrane, Environ. Sci. Technol. 38 (2004) 4040-4046.

[28] F. Gilcreas, Standard methods for the examination of water and waste water, Am. J. Public Health Nations Health 56 (1966) 387-388.

[29] H. Quanguo, Z. Lei, W. Wei, H. Rong, H. Jingke, Preparation and magnetic comparison of silane-functionalized magnetite nanoparticles, Sens. Mater 22 (2010) 285-295.

[30] A. Javidparvar, B. Ramezanzadeh, E. Ghasemi, Effect of various spinel ferrite nanopigments modified by amino propyl trimethoxy silane on the corrosion inhibition properties of the epoxy nanocomposites, Corrosion 72 (2016) 761-774.

[31] W. Jiang, F. Sun, Y. Zeng, Q. Zeng, T. Zhang, W. Tian, B. Liang, Preparation and application of separable magnetic Fe3O4-SiO2-APTES-Ag2O composite particles with high visible light photocatalytic performance, J. Environ. Chem. Eng. 6 (2018) 945-954. 
[32] D. Jiang, B. Li, Novel electrode materials to enhance the bacterial adhesion and increase the power generation in microbial fuel cells (MFCs), Water Sci. Technol. 59 (2009) 557-563.

[33] S.-H. Liu, C.-M. Chang, C.-W. Lin, Modifying proton exchange membrane in a microbial fuel cell by adding clay mineral to improve electricity generation without reducing removal of toluene, Biochem. Eng. J. 134 (2018) 101-107.

[34] E.D. Penteado, C.M. Fernandez-Marchante, M. Zaiat, P. Cañizares, E.R. Gonzalez, M.A. Rodrigo, Energy recovery from winery wastewater using a dual chamber microbial fuel cell, J. Chem. Technol. Biotechnol. 91 (2016) 1802-1808.

[35] J.R. Kim, Y. Zuo, J.M. Regan, B.E. Logan, Analysis of ammonia loss mechanisms in microbial fuel cells treating animal wastewater, Biotechnol. Bioeng. 99 (2008) $1120-1127$.
[36] J. Zhang, Q. Zhao, S. You, J. Jiang, N. Ren, Continuous electricity production from leachate in a novel upflow air-cathode membrane-free microbial fuel cell, Water Sci. Technol. 57 (2008) 1017-1021.

[37] P. Aelterman, S. Freguia, J. Keller, W. Verstraete, K. Rabaey, The anode potential regulates bacterial activity in microbial fuel cells, Appl. Microbiol. Biotechnol. 78 (2008) 409-418.

[38] A.S. Claye, J.E. Fischer, C.B. Huffman, A.G. Rinzler, R.E. Smalley, ChemInform Abstract: Solid-State Electrochemistry of the Li Single Wall Carbon Nanotube System, Cheminform 32 (2010) 109-115.

[39] Y.G. Zhao, H.Y. Shen, Q. Li, Q.H. Xia, Study on adsorption of Cr(VI) in wastewater by amino functionalized Nano-Fe3O4 magnetic polymer adsorbent, Acta Chim. Sin. 67 (2009) 1509-1514 (In Chinese). 